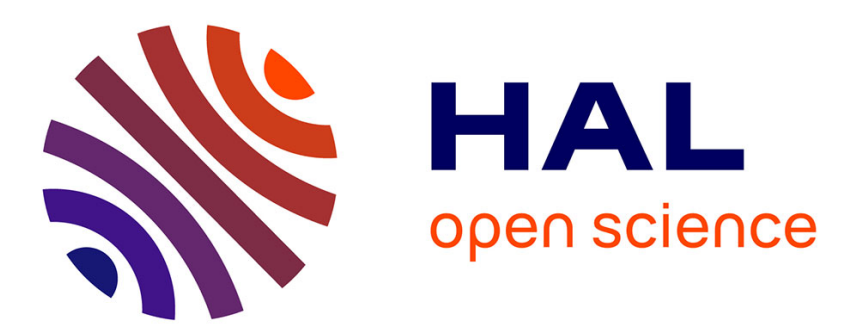

\title{
Experimental Constraints on the Crystallization of Silica Phases in Silicic Magmas
}

\author{
Caroline Martel, Michel Pichavant, Ida Di Carlo, Rémi Champallier, \\ Guillaume Wille, J.M. Castro, Karine Devineau, V.O Davydova, Alexandra \\ R.L. Kushnir
}

\section{To cite this version:}

Caroline Martel, Michel Pichavant, Ida Di Carlo, Rémi Champallier, Guillaume Wille, et al.. Experimental Constraints on the Crystallization of Silica Phases in Silicic Magmas. Journal of Petrology, 2021, 62 (1), pp.egab004. 10.1093/petrology/egab004 . insu-03178781

\section{HAL Id: insu-03178781 \\ https://hal-insu.archives-ouvertes.fr/insu-03178781}

Submitted on 24 Mar 2021

HAL is a multi-disciplinary open access archive for the deposit and dissemination of scientific research documents, whether they are published or not. The documents may come from teaching and research institutions in France or abroad, or from public or private research centers.
L'archive ouverte pluridisciplinaire HAL, est destinée au dépôt et à la diffusion de documents scientifiques de niveau recherche, publiés ou non, émanant des établissements d'enseignement et de recherche français ou étrangers, des laboratoires publics ou privés. 


\title{
Experimental Constraints on the Crystallization of Silica Phases in Silicic Magmas
}

C. Martel $^{1^{*}}$, M. Pichavant ${ }^{1}$, I. Di Carlo ${ }^{1}$, R. Champallier ${ }^{1}$, G. Wille ${ }^{2}$, J.M. Castro ${ }^{3}$, K. Devineau $^{4}$, V.O. Davydova ${ }^{5}$, A.R.L. Kushnir ${ }^{6}$

${ }^{1}$ Univ. Orléans, CNRS, BRGM, ISTO, UMR 7327, Orléans, France

${ }^{2}$ Bureau de Recherches Géologiques et Minières, BRGM, Orléans, France

${ }^{3}$ Institute of Geosciences, Johannes Gutenberg, Univ. Mainz, Mainz, Germany

${ }^{4}$ Centre de Recherches Pétrographiques et Géochimiques, CRPG, UMR 7358, CNRS-UL, Nancy, France

${ }^{5}$ Lomonosov Moscow State University, Moscow, Russia

${ }^{6}$ Ecole et Observatoire des Sciences de la Terre, EOST, Univ. Strasbourg / CNRS / UMS 830, Strasbourg, France

*Corresponding author. E-mail: caroline.martel@cnrs-orleans.fr

For submission to Journal of Petrology

\begin{abstract}
Low-pressure silica polymorphs, e.g. quartz ( $Q t z)$, tridymite $(\operatorname{Tr} d)$, and cristobalite $(\mathrm{Crs})$, are common in silicic magmas, but the conditions of their formation are still unclear. The stability fields of these polymorphs have been determined in the $\mathrm{SiO}_{2}, \mathrm{SiO}_{2}-\mathrm{H}_{2} \mathrm{O}$, and haplogranite systems, but these simple systems are not directly applicable to silica polymorph crystallization in natural silicic magmas. The present study compiles an experimental database of new and previously-published data documenting the crystallization of silica phases in natural silicic magmas and simple synthetic systems. Silica polymorphs are identified using Raman spectroscopy and their pressure-temperature domains of occurrence and chemical compositions are determined at pressures between 0.1 and $200 \mathrm{MPa}$, temperatures between 685 to $1200{ }^{\circ} \mathrm{C}$, and under $\mathrm{H}_{2} \mathrm{O}$-saturated and $\mathrm{H}_{2} \mathrm{O}$-undersaturated conditions.
\end{abstract}


$Q t z$ is the stable silica polymorph at pressures higher than 25-30 MPa, temperatures between $\sim 700$ and $950{ }^{\circ} \mathrm{C}$, and occurs for a narrow range of melt $\mathrm{SiO}_{2}$ contents ( 79-81 wt\%). Constraints on $Q t z$ stability derived from simple systems are mutually compatible with, and thus applicable to natural compositions. This is consistent with $Q t z$ compositions being close to 'pure' $\mathrm{SiO}_{2}$, both in experiments and nature. In volcanic systems, Qtz crystallization may occur in magmatic reservoirs and deep volcanic conduits.

Trd did not crystallized in the experiments conducted as part of this study despite several experiments having been performed in the $\operatorname{Trd}$ stability field. This is consistent with results from the literature which show that $T r d$ crystallization is kinetically inhibited in particular relative to $\mathrm{Cr}$. Natural $\mathrm{Tr}$. have compositions deviating substantially from 'pure' $\mathrm{SiO}_{2}$, so that stability limits determined in simple systems should not be applied directly to natural cases.

Crs was encountered at pressures below 20-30 MPa (or $\mathrm{H}_{2} \mathrm{O}$ contents $<\sim 1.5 \mathrm{wt} \%$ ), from subsolidus $\left(\sim 800{ }^{\circ} \mathrm{C}\right.$ ) to near-liquidus (up to $1040{ }^{\circ} \mathrm{C}$ ), and coexisting with melts having a large range of $\mathrm{SiO}_{2}$ contents (70-81 wt\%). The Crs stability field is much larger in natural magmas compared to pure $\mathrm{SiO}_{2}$ systems. $\mathrm{Crs}$ is a metastable phase stabilized by components (Al, Na, $\mathrm{K}$; about $3 \mathrm{wt} \%$ ) present in the silicic melt. In volcanic systems, Crs crystallization may thus be restricted to subsurface manifestations such as lava domes.

Key words: silica polymorph; silicic magma; crystallization; metastability; eruptive dynamics

\section{INTRODUCTION}

Volcanic products with bulk $\mathrm{SiO}_{2}$ contents higher than about $60 \mathrm{wt} \%$ (i.e. from andesites to rhyolites) often contain low-pressure silica polymorphs, such as Qtz, Crs, and Trd. After the report of Crs occurrence at Soufriere Hills, Montserrat (Baxter et al., 1999), there was warranted concern that the respiratory toxicity of Crs could cause a significant and previously unrecognized volcanic hazard. Yet, the studies that followed have largely concluded that impure volcanic Crs is not as bioreactive as pure Crs, and that the difficulty of dispersing significant volumes of pure $\mathrm{SiO}_{2}$ does not in fact increase risk of pulmonary disease (e.g. Horwell et al., 2012; Damby et al., 2016; Nattrass et al., 2017). Despite this, crystalline silica 
may still play a major role in volcanic dome explosivity, by conceivably modifying magma viscosity and permeability and thus exacerbating the potential for explosive activity (e.g. Horwell et al., 2013; Boudon et al., 2015; Kushnir et al., 2016). Critically, the conditions for crystalline silica formation in magmas remain poorly constrained, to the detriment of our ability to assess risks associated to dome-related eruptions.

\section{Occurrence and origin of silica polymorphs in volcanic products}

Silica polymorphs are commonly encountered in all magmatic series. In this study, we focus on calk-alkaline magmas that feed active volcanoes at convergent plate margins, mainly because of the importance of the generated volcanic risks. $Q t z$ is common in volcanic pyroclasts, such as those from the 1997 andesite at Soufriere Hills, Montserrat (Devine et al., 1998), the 1991 dacite at Mount Pinatubo, Philippines (Rutherford \& Devine, 1996), the 1991-1995 dacite at Unzen, Japan (Nakada \& Motomura, 1999), and the rhyolitic tuffs at Toba (Chesner, 1998), to name a few representative examples. Crs has been reported in numerous andesitic to rhyolitic dome products, including those at Montagne Pelée, Martinique (Martel et al., 2000; Boudon et al., 2015), Merapi, Indonesia (Damby et al., 2013; Kushnir et al., 2016), and the 2011-2012 rhyolitic lava flow at Cordón Caulle, Chile (Schipper et al., 2015). Qtz and Crs may coexist, for example in obsidian domes, including the Inyo domes, California (Swanson et al., 1989) and Chaíten, Chile (Horwell et al., 2010). Trd has been more rarely reported, but has been found in dacites from Montagne Pelée (Westercamp, 1975) and Mount Saint Helens, USA (Pevear et al., 1982; Blundy \& Cashman, 2001; Pallister et al., 2008), where it coexists with $Q t z$ and Crs. From observations of natural samples, Crs is common in silicic lava domes and flows, $Q t z$ is often present in pyroclasts from explosive eruptions, and $\operatorname{Trd}$ is rare.

In volcanic samples, silica polymorphs show different habits, which have been attributed to different mechanisms of formation. $Q t z$ and $T r d$ commonly appear as prismatic crystals (Fig. 1A-B), suggesting primary formation from a melt. Crs in volcanic samples commonly shows several habits (e.g. Ivanova et al., 2018). Firstly, Crs can appear as prismatic crystals (Fig. 1D), suggesting a primary phase grown from a melt (Martel, 2012; Schipper et al., 2015; Kushnir et al., 2016). Secondly, Crs can show 'fish-scale' cracking textures, with crystals mostly confined to the pore space (Fig. 1C), which have been interpreted to form by vaporphase deposition (Baxter et al., 1999; de Hoog et al., 2005; Reich et al., 2009; Horwell et al., 
2013, Schipper et al., 2017, 2020). Thirdly, Crs can show 'feather' textures, characterized by a multitude of indistinguishable crystals (Fig. 1C), which have been attributed to devitrification of volcanic glass (Horwell et al., 2013). The two latter types of Crs may account for the high Crs amounts (several tens of wt\%) in lava or dome samples (Schipper et al., 2015). This short overview emphasizes the large diversity of Crs textures and origins in volcanic products, implying different effects on dome explosivity. Indeed, vapour-phase Crs can occlude pores to reduce permeability, whereas melt-grown Crs affects bulk viscosity; both have the potential to increase magma explosivity, but represent very different formation mechanisms.

\section{Stability of silica polymorphs}

Under ambient pressure $(P)$, the stable silica phase in the pure $\mathrm{SiO}_{2}$ system are: $\alpha-Q t z$ at temperatures $(T)$ from 0 to $573{ }^{\circ} \mathrm{C}, \beta-Q t z$ from 573 to $870{ }^{\circ} \mathrm{C}, \mathrm{Trd}$ from 870 to $1470{ }^{\circ} \mathrm{C}$, and Crs from 1470 to $1705{ }^{\circ} \mathrm{C}$ (Heaney, 1994 and references therein; Fig. 2A). Increasing $P$ leads to the disappearance of $\operatorname{Trd}$ at $\sim 300 \mathrm{MPa}$ and then of $C r s$ at $\sim 600 \mathrm{MPa}$, in favour of $\beta-Q t z$, itself replaced by coesite and stishovite at higher $P$ (e.g. Swamy et al., 1994). Stable polymorphs appearing on the liquidus of a pure $\mathrm{SiO}_{2}$ melt are $C r s$ below $\sim 600 \mathrm{MPa}$ and $\beta-Q t z$ above this $P$ (Boettcher, 1984; Heaney, 1994; Swamy et al., 1994; Fig. 2A). Upon addition of $\mathrm{H}_{2} \mathrm{O}$, liquidus $T$ are significantly reduced. When $P$ is increased under $\mathrm{H}_{2} \mathrm{O}$-saturated conditions, $C r s, \operatorname{Trd}$ and $\beta-Q t z$ appear successively as the stable polymorphs on the liquidus of the $\mathrm{SiO}_{2}-\mathrm{H}_{2} \mathrm{O}$ system (Tuttle \& England, 1955; Tuttle \& Bowen, 1958; Boettcher, 1984; Fig. 2A). Crs is stable below $\sim 30 \mathrm{MPa}, T r d$ between 30 and $\sim 150 \mathrm{MPa}$ and $\beta-Q t z$ above $\sim 150$ MPa. $\mathrm{H}_{2} \mathrm{O}$ does not influence the $P-T$ location of the $Q t z-T r d$ boundary (Tuttle \& England, 1955; Tuttle \& Bowen, 1958).

In more complex synthetic silicic systems such as the haplogranite $\left(\mathrm{NaAlSi}_{3} \mathrm{O}_{8}-\mathrm{KAlSi}_{3} \mathrm{O}_{8}-\right.$ $\left.\mathrm{SiO}_{2}-\mathrm{H}_{2} \mathrm{O}\right)$ system, the three polymorphs $C r s, \mathrm{Trd}$ and $\beta-Q t z$ can crystallize as stable phases at constrained liquidus $T$ and melt compositions (Tuttle \& Bowen, 1958). The main stable polymorph on the $\mathrm{SiO}_{2}$-rich ternary liquidus surface under dry/ambient $P$ conditions and at $P$ $\leq 25-30 \mathrm{MPa}$ in $\mathrm{H}_{2} \mathrm{O}$-saturated systems, is $T r d$. In these systems, Crs and $\beta-Q t z$ are respectively confined to the high $T$ / high $\mathrm{SiO}_{2}$ corner and low $T$ near-minimum region of the ternary system (Fig. 2B). Upon increasing $P$ under $\mathrm{H}_{2} \mathrm{O}$-saturated conditions, liquidus $T$ 
markedly decrease and both $C r s$ and $\operatorname{Trd}$ are progressively replaced by $\beta-Q t z . T r d$ is totally eliminated from the liquidus surface between 100 and $150 \mathrm{MPa}$ (Fig. 2B), consistent with the $P-T$ location of the $Q t z-T r d$ inversion in the $\mathrm{SiO}_{2}-\mathrm{H}_{2} \mathrm{O}$ system (Fig. 2A), and $\beta-Q t z$ becomes the sole silica polymorph on the $\mathrm{H}_{2} \mathrm{O}$-saturated liquidus up to at least $1000 \mathrm{MPa}$ (Tuttle \& Bowen, 1958; Luth et al., 1964).

\section{Chemistry of the silica polymorphs}

In simple systems, silica polymorphs are implicitly assumed to have compositions near pure $\mathrm{SiO}_{2}$ (no solid solution) which implies that, in principle, their stability fields extend unchanged in natural magmas. However, the validity of this proposition depends on how close to $100 \mathrm{wt} \% \mathrm{SiO}_{2}$ the compositions of silica polymorphs are in both experiments and nature. $Q t z$ seems to fulfil this condition, although we note that phase compositions were not determined by electron microprobe in early studies (e.g. Tuttle \& Bowen, 1958). In contrast, experimentally grown $\mathrm{Trd}$ and $\mathrm{Crs}$ incorporate high concentrations of 'impurities' i.e. cations other than Si (Holmquist, 1961; Roy \& Roy, 1964; Dapiaggi et al., 2015). This is consistent with $C r s$ in volcanic products having $>1 \mathrm{wt} \% \mathrm{Al}_{2} \mathrm{O}_{3}$ (up to $\sim 3 \mathrm{wt} \%$ ) and significant alkali (especially $\mathrm{Na}_{2} \mathrm{O}$ ) contents (Pallister et al., 2008; Horwell et al., 2012; Schipper et al., 2015, 2020; Ivanova et al., 2018), whereas $Q t z$ generally hosts < 1 wt $\% \mathrm{Al}_{2} \mathrm{O}_{3}$ (Pallister et al., 2008; Horwell et al., 2012; Breiter et al., 2012). For Trd, the available data (Pallister et al., 2008) indicate the presence of $\mathrm{Al}_{2} \mathrm{O}_{3}$ and $\mathrm{Na}_{2} \mathrm{O}$ in smaller concentrations than in Crs but in greater concentrations compared to $Q t z$. It appears that both $\operatorname{Tr} d$ and $C r s$ deviate substantially from $100 \mathrm{wt} \% \mathrm{SiO}_{2}$, so that stabilities of $\mathrm{Trd}$ and $\mathrm{Cr}$ s determined in simple systems (where they are assumed to be pure $\mathrm{SiO}_{2}$ ) cannot be applied directly to natural magmas. Conditions of $\operatorname{Trd}$ and Crs crystallization thus remain to be investigated in complex systems using appropriate methods (e.g. Raman spectroscopy) for the identification of silica polymorphs in experimental charges.

\section{Scope of the study}

Based on phase equilibrium results in simple systems (i.e. $\mathrm{SiO}_{2}, \mathrm{SiO}_{2}-\mathrm{H}_{2} \mathrm{O}$, haplogranite), silica polymorphs expected to crystallize under common $P-T$ volcanic conditions $(P<200$ MPa and $700<T<1100{ }^{\circ} \mathrm{C}$ ) would be $Q t z$ and $\operatorname{Trd}$ (Fig. 2). Crs would be expected to be 
totally absent given the 'low' $T$ range above. Yet, in natural products, Qtz and Crs are commonly observed whereas $\operatorname{Tr} d$ is rare. To explain this contrast between experimental and natural observations, the basic thesis developed in this paper is that simple systems provide only a simplified framework for the crystallization of silica phases.

In this study, an experimental database documenting the crystallization of silica phases in natural silicic magmas and simple synthetic systems is detailed. To do this, we have compiled previously published data, as well as conducted a suite of experiments. The data constrain the $P-T$ domains of occurrence of silica polymorphs (identified using Raman spectroscopy) and their chemical compositions. Mechanisms of crystallization are discussed and the importance of kinetic factors is emphasized. Results provide a framework to use silica polymorphs as indicators of eruptive processes and conditions in volcanic systems.

\section{EXPERIMENTAL AND ANALYTICAL METHODS}

\section{Samples and experimental conditions}

We use data from seven series of crystallization experiments. These natural and synthetic series have starting melt compositions $\geq 70 \mathrm{wt} \% \mathrm{SiO}_{2}$, and are dominated by four components: quartz, albite, anorthite and orthoclase. Their compositions are reported in Tab. 1.

The series reported in the literature include bulk rhyolitic magmas from Cordón Caulle (CC; Castro et al., 2013 and J.M. Castro, pers. comm.) and Chaíten (CHAI; Castro \& Dingwell, 2009), both volcanoes from Chile. The low bulk $\mathrm{SiO}_{2}(\sim 70 \mathrm{wt} \%)$ of the $\mathrm{CC}$ rhyolite distinguishes this sample from the others that contain 75-77 wt\% $\mathrm{SiO}_{2}$. Rhyolitic glasses from Montagne Pelée, Martinique (PEL; Martel \& Poussineau, 2007; Martel, 2012) and Soufriere Hills, Montserrat (SH2; Martel \& Schmidt, 2003) are representative of interstitial melts in equilibrium with phenocrysts in the two respective bulk andesitic magmas (Martel et al., 1998; 1999; Barclay et al., 1998). Simple synthetic systems include one haplogranite (HPG; $\mathrm{Si}, \mathrm{Al}, \mathrm{Na}, \mathrm{K})$. The HPG system simulates near cotectic silica-feldspar crystallization from evolved liquids enriched in $\mathrm{K}_{2} \mathrm{O}$. The $\mathrm{SiO}_{2}$ content of the HPG (76.7 wt\%, Devineau et al., 2020 ) is similar to natural rhyolites. We also include results in the haplogranite system (Tuttle 
\& Bowen, 1958), in particular the data on the ternary minima (hereafter noted $\mathrm{HPG}_{\mathrm{m}}$ to distinguish it from the HPG composition).

The new experiments concern 3 experiments to complete the PEL series at $P<50 \mathrm{MPa}$ and $900<T<1000{ }^{\circ} \mathrm{C}$, as well as 43 experiments starting with one haplotonalite (HTN; Si, Al, $\mathrm{Na}, \mathrm{Ca}$ ). The HTN system models the behaviour of $10 \mathrm{w}-\mathrm{K}_{2} \mathrm{O}$ silicic liquids crystallizing plagioclase before $Q t z$ and K-feldspar, a common case in orogenic intermediate magmas (e.g. Martel et al., 1999; Scaillet \& Evans, 1999; Pichavant et al., 2018). It contains 76.7 wt\% $\mathrm{SiO}_{2}$, a content identical to HPG, and $13 \mathrm{wt} \%$ normative anorthite, similar to those of PEL and SH2.

A total of 126, including 46 new, experimental charges from these seven series have been used and the nature of the crystalline silica phase, when present, has been systematically determined by Raman spectroscopy. The experimental and analytical methods for the new experiments are detailed in SM1; the methods employed for the other series are available in the literature (for references see Tab. 1). The $P-T$ conditions and melt $\mathrm{H}_{2} \mathrm{O}$ contents for all experiments are summarized in Tab. 2. Most charges are products of crystallization of a crystal-free melt under constant $P-T$ conditions, but two result from isothermal instantaneous decompression of an initially crystal-free melt (D5 and D6, both for PEL composition) followed by crystallization at a constant final $P$. About half of the samples were initially saturated with $\mathrm{H}_{2} \mathrm{O}$. Among the other half, most residual glasses are $\mathrm{H}_{2} \mathrm{O}$ saturated.

\section{Raman spectroscopy}

The presence of crystalline silica was first checked by scanning electron microscopy (SEM; Merlin Compact Zeiss, ISTO, Orléans, France), in all but $\mathrm{HPG}_{\mathrm{m}}$ experimental charges. The nature of the silica phase was determined in 35 experimental charges by Raman spectroscopy, using either a Renishaw InVia spectrometer at a wavelength of $514 \mathrm{~nm}$ and a maximum power of $100 \mathrm{~mW}$ (BRGM-ISTO, Orléans, France) or a Horiba-Yvon Labram-HR Raman microscope operating in conjunction with a solid-state laser at a wavelength of $532 \mathrm{~nm}$ and maximum power of $200 \mathrm{~mW}$ (Mainz University, Mainz, Germany). Two samples were analyzed using a SEM-coupled Raman spectrometer that allows Raman imaging. Coupled SEM observations and Raman imaging were performed on a Zeiss-WITec RISE microscope combining a ZEISS Gemini SEM 300 LV-FE-SEM to a WITec confocal Raman imaging system (WITec, Ulm, Germany) (Wille et al., 2018). The RISE confocal Raman imaging 
system is equipped with a UHTS300 spectrometer, a Zeiss 100x vacuum objective (Numerical Aperture 0.75) mounted inside the SEM chamber, using a $532 \mathrm{~nm}$ laser radiation wavelength. Coupled SEM-EDS (energy-dispersive spectrometer) and Raman imaging were performed on non-coated samples at $\mathrm{HV}=15 \mathrm{kV}$ under nitrogen pressure of $20 \mathrm{~Pa}$ (Cergy Paris University, Neuville/Oise, France). Raman spectra of selected samples are shown in Fig 3.

\section{Chemical analyses}

The experimental and natural samples were examined using a scanning electron microscope (MIRA3 TESCAN at ISTO), in order to identify silica crystals favourable for chemical analysis using an electron microprobe (EMP; Cameca SX Five at ISTO). Alkalis were analysed first to minimize their migration under the electron beam. The EMP conditions were set to an acceleration voltage of $15 \mathrm{kV}$, a beam current of $6 \mathrm{nA}$, and peak/background counting times of $10 / 5 \mathrm{~s}$ for all elements. Under these conditions, the detection limits are of the order of 900 ppm for Si and K, about 400 ppm for Al, Na, and Ca, and of 1200-2000 ppm for Fe and $\mathrm{Ti}$. The analytical errors on major elements were calculated at $\sim 1 \%$ (relative) for $\mathrm{SiO}_{2}, \mathrm{Al}_{2} \mathrm{O}_{3}$ and $\mathrm{CaO}$, and $5 \%$ for $\mathrm{Na}_{2} \mathrm{O}$. Schipper et al. (2020) reported Na migration under the electron beam during cristobalite analyses, as such, we have tested the effect of defocusing the beam under the above conditions. We did not observe differences in $\mathrm{Na}$ content between the focused (spot size of $1 \mu \mathrm{m})$ and defocused $(10 \times 10 \mu \mathrm{m})$ beam. This suggests that by analysing Na first, using a low current (e.g. $6 \mathrm{nA}$ ), and low peak/background counting times (e.g. 10/5 s), we may reasonably prevent sodium loss during analysis of crystalline silica.

\section{RESULTS}

\section{The new haplotonalite (HTN) series}

In the new HTN series, plagioclase and $Q t z$ were the only mineral phases to crystallize at 200 $\mathrm{MPa}(\mathrm{SM} 2 \mathrm{~A})$. Plagioclase is the liquidus phase from about $900{ }^{\circ} \mathrm{C}$ under $\mathrm{H}_{2} \mathrm{O}$ saturation $(\sim 7.0$ 
wt $\% \mathrm{H}_{2} \mathrm{O}$ ) to $\sim 1200{ }^{\circ} \mathrm{C}$ under strongly $\mathrm{H}_{2} \mathrm{O}$-undersaturated conditions $\left(0-1 \mathrm{wt} \% \mathrm{H}_{2} \mathrm{O}\right.$ in the melt). It is followed by $Q t z$ in the crystallization sequence and the $Q t z$-plagioclase cotectic runs more or less parallel to the liquidus, being shifted by about $100{ }^{\circ} \mathrm{C}$ towards lower $T$ for a given melt $\mathrm{H}_{2} \mathrm{O}$ content (SM2B).

The melt composition ranges from 76.7 to $77.2 \mathrm{wt} \% \mathrm{SiO}_{2}$ for charges close to the liquidus (SM3, vs. 76.7 wt\% $\mathrm{SiO}_{2}$ in the starting glass; Tab. 1). The $\mathrm{SiO}_{2}$ content of the melt increases with progressive crystallization, reaching 79.9 to $81.4 \mathrm{wt} \%$ along the $Q t z$-plagioclase cotectic (SM3). The near-liquidus plagioclase has a composition of $\sim \mathrm{An}_{48}$ (SM2B and SM3). On the cotectic curve, $Q t z$ coexists with about 20 vol\% of $\sim \mathrm{An}_{30}$ plagioclase (SM2B).

\section{Liquidus relations and phases}

The $\mathrm{H}_{2} \mathrm{O}$-saturated liquidus relations for the investigated compositions are illustrated in Fig. 4A. For PEL, SH2, CHAI, and CC, the data enable liquidus curves to be constructed at different $P$. Liquidus curves for the three $75-77 \mathrm{wt} \% \mathrm{SiO}_{2}$ rhyolites run close to each other, from $800-850{ }^{\circ} \mathrm{C}$ at $200 \mathrm{MPa}$ to $\sim 950-1000{ }^{\circ} \mathrm{C}$ at $50 \mathrm{MPa}$. A marked shift towards higher liquidus $T$ is observed at $P<50 \mathrm{MPa}$ for the PEL composition (e.g. $\sim 1075{ }^{\circ} \mathrm{C}$ at $25 \mathrm{MPa}$, see also Hammer \& Rutherford, 2002; Castro \& Dingwell, 2009; Martel, 2012). In contrast, the liquidus $T$ of the $70 \mathrm{wt} \% \mathrm{SiO}_{2} \mathrm{CC}$ rhyolite lies above $925^{\circ} \mathrm{C}$ at $200 \mathrm{MPa}$ and between 950 and $975{ }^{\circ} \mathrm{C}$ at $50 \mathrm{MPa}$ (Castro et al., 2013), distinctly higher than the range for the three 75-77 $\mathrm{wt} \% \mathrm{SiO}_{2}$ rhyolites at $200 \mathrm{MPa}$. The CC liquidus is also much steeper than the PEL, SH2, and CHAI curves. HPG has a liquidus $T$ of $\sim 720{ }^{\circ} \mathrm{C}$ at $200 \mathrm{MPa}$ (Devineau et al., 2020), i.e. lower by $>100{ }^{\circ} \mathrm{C}$ than liquidus $T$ for the other series and consistent with its composition close to the $200 \mathrm{MPa}$ haplogranite minimum $\left(\mathrm{HPG}_{\mathrm{m}}\right)$. For the $\mathrm{HTN}$ series, the $200 \mathrm{MPa} \mathrm{H}_{2} \mathrm{O}$-saturated liquidus $T$ is $\sim 875^{\circ} \mathrm{C}(\mathrm{SM} 2 \mathrm{~B})$.

Liquidus phases for the natural rhyolites are either feldspar, pyroxene or Fe-Ti oxides (Martel et al., 1999; Castro \& Dingwell, 2009; Martel \& Schmidt, 2003; Martel, 2012; Castro et al., 2013). None of the rhyolites investigated here has a silica polymorph on the liquidus. The two simple synthetic compositions both have feldspar on their liquidus: plagioclase for HTN (SM2B) and K-feldspar for HPG (Devineau et al., 2020). 


\section{Silica polymorphs}

Quartz. Experiments where Qtz saturation is reported are compiled in Tab. 2. Qtz largely dominates our experimental database and mostly appears as $<50 \mu \mathrm{m}$ prismatic crystals (Fig. 5A; SM2A). The Qtz saturation curves are shown in Fig. 4B for the different starting compositions. At $200 \mathrm{MPa}$ under $\mathrm{H}_{2} \mathrm{O}$-saturated conditions, Qtz saturates at $\sim 780{ }^{\circ} \mathrm{C}$ in $\mathrm{HTN}$ (SM2B). Under the same conditions in HPG, Qtz crystallizes at $\sim 690{ }^{\circ} \mathrm{C}$ (Devineau et al., 2020). In the $\mathrm{H}_{2} \mathrm{O}$-saturated haplogranite ternary minimum $\left(\mathrm{HPG}_{\mathrm{m}}\right), Q t z$ crystallizes at $685{ }^{\circ} \mathrm{C}$ at $200 \mathrm{MPa}, 720^{\circ} \mathrm{C}$ at $100 \mathrm{MPa}$, and $770{ }^{\circ} \mathrm{C}$ at $50 \mathrm{MPa}$ (Tuttle \& Bowen, 1958; Fig. 2). It is worth recalling that the ternary minimum defines the conditions of co-saturation of a silica phase with an alkali feldspar on the liquidus. Thus, under $\mathrm{H}_{2} \mathrm{O}$-saturated conditions for a given $P$ in the haplogranite system, the saturation $T$ of $Q t z$ (or another silica polymorph) cannot be lower than the ternary minimum $T$. For PEL, SH2 and CHAI, no Qtz saturation data are available at $200 \mathrm{MPa}$. Under $\mathrm{H}_{2} \mathrm{O}$-saturated conditions, the Qtz saturation curve in PEL extends from $800-850{ }^{\circ} \mathrm{C}$ at $100 \mathrm{MPa}$ to $925^{\circ} \mathrm{C}$ at $50 \mathrm{MPa}$ (Martel, 2012; Fig. 4B). In CHAI, the $Q t z$ saturation curve extends from $\sim 775^{\circ} \mathrm{C}$ at $100 \mathrm{MPa}$ to $800-825^{\circ} \mathrm{C}$ at $50 \mathrm{MPa}$ (Castro \& Dingwell, 2009; Fig. 4B). In CC, Qtz did not saturate under the experimental conditions investigated (Castro et al., 2013).

The $200 \mathrm{MPa}$ experiments on HTN and HPG constrain the effect of $\mathrm{H}_{2} \mathrm{O}$ on silica polymorph formation. $Q t z$ is the only silica polymorph that crystallized in the $\mathrm{H}_{2} \mathrm{O}$-undersaturated charges (Tab. 2), thus lowering the melt $\mathrm{H}_{2} \mathrm{O}$ content has no influence on the nature of the $\mathrm{SiO}_{2}$ phase in the investigated $P-T$ range. Yet, $Q t z$ saturation is progressively shifted toward higher $T$ for a given $P$. For HTN, $Q t z$ saturation occurs at $\sim 1050{ }^{\circ} \mathrm{C}$ for $0-1 \mathrm{wt} \% \mathrm{H}_{2} \mathrm{O}$ (vs. $\sim 780{ }^{\circ} \mathrm{C}$ for $7 \mathrm{wt} \% \mathrm{H}_{2} \mathrm{O}$; SM2B). For HPG, Qtz saturates at $750{ }^{\circ} \mathrm{C}$ for $5.0 \mathrm{wt} \% \mathrm{H}_{2} \mathrm{O}$ ), as opposed to $690{ }^{\circ} \mathrm{C}$ for $6.2 \mathrm{wt} \% \mathrm{H}_{2} \mathrm{O}$ (Devineau et al., 2020).

Tridymite. None of the natural or experimental compositions investigated in this study crystallized $\operatorname{Tr}$.

Cristobalite. The experimental charges that contain Crs are reported in Tab. 2. Crs mostly appears as $<10 \mu \mathrm{m}$ prismatic crystals (Fig. 3B, 5B), in agreement with primary crystallization from the melt. Yet, in charges with large amounts of excess $\mathrm{H}_{2} \mathrm{O}$ vapour (several wt\% above solubility), the prismatic crystals coexist with larger 'fish-scale' patches (Fig. 5C). Interestingly, 'fish-scale' Crs was not observed in the absence of prismatic crystals. Cocrystallization of $Q t z$ and $C r s$ was observed in one experimental charge, constraining the $Q t z-$ 
Crs boundary at around $925^{\circ} \mathrm{C}$ and $25 \mathrm{MPa}$ in the PEL composition (Fig. 4C). Qtz in that charge appears as $\sim 50 \mu \mathrm{m}$ spongy patches likely reflecting disequilibrium textures. $\operatorname{Crs}$ is found between $850{ }^{\circ} \mathrm{C}$ and $1040{ }^{\circ} \mathrm{C}$ and restricted to $\mathrm{H}_{2} \mathrm{O}$-saturated $P$ below $30 \mathrm{MPa}$ (Fig. 4C). There are small differences in Crs occurrence between the rhyolites: Crs crystallizes between 25 and $50 \mathrm{MPa}$ in $\mathrm{SH} 2$ (at $860{ }^{\circ} \mathrm{C}$ ), between 10 and $25 \mathrm{MPa}$ in PEL (at $850{ }^{\circ} \mathrm{C}$ ), and between 3 and $20 \mathrm{MPa}$ in CC (at 860-900 ${ }^{\circ} \mathrm{C}$ ). Crs also crystallizes in PEL between 25 and 30-40 MPa at $1040{ }^{\circ} \mathrm{C}$, i.e. near the liquidus (Fig. 4A), although its identification in the 25 MPa charge could not be confirmed by Raman spectroscopy due to the small size of the crystals.

\section{Composition of the silica polymorphs}

New electron microprobe analyses of experimental and natural $Q t z$ and $C r s$ have been reported in Tab. 3. In the simple HPG system (run 33-4c from Devineau et al., 2020), Qtz is almost pure $\mathrm{SiO}_{2}$, showing only about $0.2 \mathrm{wt} \%$ of other components, mainly $\mathrm{Al}_{2} \mathrm{O}_{3}(0.12 \pm$ $0.08 \mathrm{wt} \%$ ), which is consistent with the $<0.1 \mathrm{wt} \%$ impurities in $Q t z$ of the natural samples of Soufrière of Guadeloupe. Yet, the HTN system and the PEL rhyolite both show up to $0.9 \mathrm{wt} \%$ impurities including about $0.6 \mathrm{wt} \% \mathrm{Al}_{2} \mathrm{O}_{3}$, which likely reflect analyses of crystals smaller than the microprobe beam size and which are therefore contaminated by glass. In contrast, Crs crystallized in the PEL composition contains about $3 \mathrm{wt} \%$ of components other than $\mathrm{SiO}_{2}$, mainly $\mathrm{Al}_{2} \mathrm{O}_{3}(2 \mathrm{wt} \%)$ and alkalis $(1 \mathrm{wt} \%)$, in agreement with the Crs compositions in its natural volcanic counterpart. Trd was not observed in the experiments of this study, but analyses of natural Trd from Bezymianny 2017 lava flows show about 1.3 wt\% impurities consisting of $\sim 1 \mathrm{wt} \% \mathrm{Al}_{2} \mathrm{O}_{3}$ and $0.3 \mathrm{wt} \% \mathrm{Na}_{2} \mathrm{O}$ (V.O. Davydova, pers. comm.), confirming impurity contents in $\operatorname{Tr} d$ between those in $Q t z$ and $C r s$.

\section{Melt compositions}

The melt compositions are given in SM3 for HTN and in SM4 for the new PEL experiments and new analyses of CC and CHAI samples. For the other series, the glass compositions are given in the literature (see Tab. 2 for references). $\mathrm{SiO}_{2}$ concentrations of low $P(\leq 100 \mathrm{MPa})$ $\mathrm{H}_{2} \mathrm{O}$-saturated melts are plotted as a function of either $\mathrm{H}_{2} \mathrm{O}$ content or $P$ in Fig. 6. A distinction is drawn between charges with $Q t z$, with $C r s$, and without silica phase. The data 
define conditions of $Q t z$ saturation in the melt when either $\mathrm{H}_{2} \mathrm{O}$ content or $P$ is varied from $\sim 100 \mathrm{MPa}$ down to $\sim 20 \mathrm{MPa}$. The resulting saturation curve has a negative slope and extends from $\sim 78-79$ wt $\% \mathrm{SiO}_{2}$ at $\sim 4 \mathrm{wt} \% \mathrm{H}_{2} \mathrm{O}$ to $\sim 79-80 \mathrm{wt} \% \mathrm{SiO}_{2}$ at $\sim 1.5 \mathrm{wt} \% \mathrm{H}_{2} \mathrm{O}$. The Crsbearing charges are confined to below $\sim 2 \mathrm{wt} \% \mathrm{H}_{2} \mathrm{O}$ (or below $\sim 25 \mathrm{MPa}$ ). Remarkably, Crs crystallizes over a large range of glass $\mathrm{SiO}_{2}$ contents, from 72 to $81 \mathrm{wt} \%$, i.e. from within the region saturated with respect to either $Q t z$ or $\operatorname{Trd}$ to the silica-undersaturated region. $C r s$ is often the sole silica phase present as in PEL ( 76.5 wt\% $\left.\mathrm{SiO}_{2}\right)$ and in CC $\left(72-73 \mathrm{wt} \% \mathrm{SiO}_{2}\right)$. As a subliquidus phase, $C r s$ crystallizes in melts from $\sim 77$ to $\sim 81 \mathrm{wt} \% \mathrm{SiO}_{2}$. The horizontal Qtz-Crs boundary (Fig. 6) emphasizes that the transition from a Qtz- to a Crs-bearing assemblage is not controlled by the $\mathrm{SiO}_{2}$ content of the melt.

\section{DISCUSSION}

\section{The applicability of silica phase crystallization in simple systems to that in natural magmas}

Quartz. In our database limited to $P$ up to $200 \mathrm{MPa}$ and $T>680{ }^{\circ} \mathrm{C}, Q t z$ saturation in the rhyolite experiments is observed in a relatively narrow $P$ range: from 25 to $100 \mathrm{MPa}$ under $\mathrm{H}_{2} \mathrm{O}$-saturated conditions. In the HPG and HTN systems, Qtz is present at $200 \mathrm{MPa}$ (Tab. 2; Fig. 4B). Previous studies on haplogranitic melts have reported Qtz crystallization up to 800$1000 \mathrm{MPa}$ (Luth et al., 1964; Holtz et al., 2001) and in excess of $\sim 1000 \mathrm{MPa}$ in natural silicic melts (e.g. Stern \& Wyllie, 1981; Conrad et al., 1988; Prouteau \& Scaillet, 2003). Concerning $T, Q t z$ saturation is observed between 750 and $925^{\circ} \mathrm{C}$ in the studied rhyolites, extending to between 690 and $1050{ }^{\circ} \mathrm{C}$ in the HPG and HTN systems. Previous studies of the haplogranite system have reported $Q t z$ to be present from approximately $650{ }^{\circ} \mathrm{C}$ (Luth et al., 1964) to 1200 ${ }^{\circ} \mathrm{C}$ (Holtz et al., 2001), thus encompassing (and even expanding) the volcanic $T$ range considered here. For natural magmas, maximum $T$ of $900-950{ }^{\circ} \mathrm{C}$ have been found previously for Qtz crystallization in a rhyolite (Conrad et al., 1988) and a dacite (Prouteau \& Scaillet, 2003), overlapping with the $T$ range found for the rhyolites contained in the present database (Tab. 2). Qtz has been reported to crystallize at higher $T$ (up to $1100-1200{ }^{\circ} \mathrm{C}$ ) at $0.1 \mathrm{MPa}$ in several natural and synthetic rhyolites (Brugger et al., 2003). However, the identification of the silica phase as Qtz was not confirmed by unequivocal methods such as Raman 
spectroscopy in most of these studies (e.g. Conrad et al., 1988; Brugger et al., 2003). Overall, what emerges is the wide range of $P-T$ conditions appropriate for $Q t z$ crystallization in silicic melts. Most importantly, the $Q t z$ saturation conditions deduced from simple systems are consistent with those from natural compositions (Fig. 4B). There is also general agreement between $\mathrm{SiO}_{2}$ melt compositions at $Q t z$ saturation for the three natural rhyolites and for the haplogranite system. In comparison, for the HTN composition, Qtz saturation occurs for melt $\mathrm{SiO}_{2}$ concentrations higher by $\sim 1 \mathrm{wt} \%$ than in the other charges (Fig. 6), consistent with the respective positions of eutectics in the $Q t z$-albite and $Q t z$-anorthite systems (Tuttle $\&$ Bowen, 1958; Stewart, 1967; Boettcher et al., 1984). Thus, the location of the Qtz saturation curve in Fig. 6 is weakly dependent on the melt composition. Therefore, for the prediction of $Q t z$ occurrences, experimental results in simple systems are appropriate and applicable to natural magmas. This conclusion is consistent with the observation that $Q t z$ chemistries are close to pure $\mathrm{SiO}_{2}$, both in experiments and nature (Tab. 3 and see above).

Tridymite. The lack of $T r d$ in our experiments is attributed primarily to $P$ - $T$ conditions being mostly outside the $\operatorname{Tr} d$ stability field. For example, at $200 \mathrm{MPa}$, the HTN charge at $1000{ }^{\circ} \mathrm{C}$ (the hottest where $Q t z$ saturation is reported, SM2B; 1000_1.0, Tab. 2) is $\sim 250{ }^{\circ} \mathrm{C}$ lower than the temperature of the $Q t z-T r d$ inversion at this $P$ (Fig. 2A). Also, in natural rhyolites, $\operatorname{Tr} d$ should form in $\mathrm{SiO}_{2}$-saturated melts at $T>870{ }^{\circ} \mathrm{C}$, in agreement with the minimum $T$ needed for $\mathrm{Trd}$ to crystallize as the stable polymorph (Fig. 2A). For example, the CC charge at $900{ }^{\circ} \mathrm{C}$ and $3 \mathrm{MPa}$ (Puy\#3, Tab. 2) and the PEL charges at $1040{ }^{\circ} \mathrm{C}, 25$ and $10 \mathrm{MPa}$ (VM250 and VM100, respectively, Tab. 2) have melt $\mathrm{SiO}_{2}$ contents far from the saturation curve shown in Fig. 6, thus explaining why they did not crystallize $\mathrm{Trd}$. Among the $\mathrm{SiO}_{2}$-saturated experiments above $870{ }^{\circ} \mathrm{C}$, the PEL charge at $925^{\circ} \mathrm{C}$ and $50 \mathrm{MPa}$ (925PEL50, Tab. 2) is very close to the $Q t z-T r d$ boundary but still within the $Q t z$ stability field for this $P$ (Fig. 2A). The only charge that meets the $\mathrm{SiO}_{2}$-saturation and $T$ conditions to crystallize stable $\mathrm{Trd}$, i.e. the PEL charge at $925{ }^{\circ} \mathrm{C}$ and $25 \mathrm{MPa}$ (925PEL25, Tab. 2), does not contain Trd. In simple systems, $\mathrm{Trd}$ was present only in some $\mathrm{SiO}_{2}$-alkali systems at $0.1 \mathrm{MPa}$ (Hirschmann et al., 2008), and upon melting of a Qtz-anorthite mixture at $1040{ }^{\circ} \mathrm{C}, 100 \mathrm{MPa}$ and under $\mathrm{H}_{2} \mathrm{O}$ saturated conditions (Stewart, 1967), which is a rare case of $\operatorname{Trd}$ being present at $P>0.1 \mathrm{MPa}$. Thus, to date, $\operatorname{Tr} d$ has not been experimentally crystallized from haplogranitic melts nor from natural silicic magma compositions; from this point of view, the PEL charge 925PEL25 (Tab. 2 ) is no exception. Although $\operatorname{Tr} d$ was apparently 'encountered in some experiments' (Tuttle \& Bowen, 1958, p. 28), its quasi absence in the volcanologically relevant near-minimum region 
of the haplogranite system can be understood by noting that experimental data are available either at $0.1 \mathrm{MPa}$ (where crystallization of near-minimum melts is nearly impossible; Schairer, 1950; Schairer \& Bowen, 1935; 1947a; 1955; 1956) or at $50 \mathrm{MPa}$ under $\mathrm{H}_{2} \mathrm{O}-$ saturated conditions (where the liquidus phase is $Q t z$; Tuttle \& Bowen, 1958). We conclude that experimental constraints on conditions of $\operatorname{Trd}$ crystallization in simple systems remain theoretical only and are still absent in natural magmas.

Cristobalite. The appearance of Crs is restricted to the rhyolite experiments (Tab. 2; Fig. 4C), which suggests that the conditions for Crs crystallization from hydrated simple melts were not met in the studied range of conditions. In simple systems, however, Crs readily crystallizes in binary $\mathrm{SiO}_{2}$-alkali (Kracek et al., 1937) and in ternary systems such as $\mathrm{Na}_{2} \mathrm{O}-\mathrm{Al}_{2} \mathrm{O}_{3}-\mathrm{SiO}_{2}$ and $\mathrm{K}_{2} \mathrm{O}-\mathrm{Al}_{2} \mathrm{O}_{3}-\mathrm{SiO}_{2}$ (Schairer \& Bowen, 1947a; 1955; 1956), occurring both above and below $1470{ }^{\circ} \mathrm{C}$ (the Crs-Trd inversion $T$ at $0.1 \mathrm{MPa}$; Fig. 2A), that is to say, as a stable and a metastable phase. $\mathrm{Crs}$ has been grown at high $T\left(1200-1600{ }^{\circ} \mathrm{C}\right)$ and $0.1 \mathrm{MPa}$ from highly silicic (> 80-90 wt\% $\mathrm{SiO}_{2}$ ) haplogranitic compositions (Schairer, 1950; Schairer \& Bowen, $1935 ; 1955 ; 1956)$. Therefore, the Crs-bearing charges in our database have counterparts in simple systems, but at $T\left(>1000{ }^{\circ} \mathrm{C}\right.$ ) and melt compositions (very $\mathrm{SiO}_{2}$-rich and $\mathrm{H}_{2} \mathrm{O}$-free) remote from natural conditions. For natural silicic magmas, no other Crs-bearing charges than those listed in Tab. 2 apparently exist in the literature. Chemistries of Crs crystallized in the haplogranite system are unknown but $C r s$ in the PEL rhyolite shows significant amounts of $\mathrm{Al}_{2} \mathrm{O}_{3}, \mathrm{Na}_{2} \mathrm{O}$ and $\mathrm{K}_{2} \mathrm{O}$ (Tab. 3), indicating deviation from pure $\mathrm{SiO}_{2}$. We conclude that experimental constraints in simple systems are difficult to use to predict Crs occurrence in nature and that results in natural silicic magmas need more study to understand the significance of Crs in the experiments.

\section{Stable versus metastable crystallization of the silica phases}

There are three charges in which $Q t z$ occurs outside of its theoretical stability field. The first case is the $925{ }^{\circ} \mathrm{C}, 25 \mathrm{MPa}$ charge (925PEL25, Tab. 2) where Qtz, coexisting with $\mathrm{Crs}$, is present above its theoretical stability limit (see Roy \& Roy, 1964; Venezia et al., 2001 for similar cases). The $Q t z$ in this charge displays a 'spongy' texture that likely suggests disequilibrium crystallization. The two other cases are the $\mathrm{H}_{2} \mathrm{O}$-poor $850{ }^{\circ} \mathrm{C}$ PEL experiments at $\leq 10 \mathrm{MPa}$ where $Q t z$ failed to crystallize and $C r s$ is present (Tab. 2; Fig. 4C). Yet, apart from these exceptions, the experimental phase compositions are chemically homogeneous and 
follow consistent trends (e.g. melt $\mathrm{SiO}_{2}$ content at silica saturation as a function of $P$; Fig. 6), generally suggesting near-equilibrium in $Q t z$-bearing charges.

Primary $C r s$ grown from the melt was found from 850 to $1040{ }^{\circ} \mathrm{C}$, that is to say in a $T$ range more than $400{ }^{\circ} \mathrm{C}$ cooler than the lower stability limit for $\mathrm{Crs}$ at $0.1 \mathrm{MPa}\left(1470{ }^{\circ} \mathrm{C}\right.$; Fig. $\left.2 \mathrm{~A}\right)$. This is consistent with findings in many silicate systems where Crs may crystallize and persist metastably for long periods of time at $T$ within the stability range of $\operatorname{Trd}$ (e.g. Schairer \& Bowen, 1947b). Crs also crystallized instead of $Q t z$ in the two $850^{\circ} \mathrm{C}$ PEL experiments at and below $10 \mathrm{MPa}$ (Tab. 2; Fig. 4C). Crs is found for a large range of glass $\mathrm{SiO}_{2}$ content, from 72 to $81 \mathrm{wt} \%$. Crs coexists in some $\mathrm{CC}$ and PEL charges with melts having $\mathrm{SiO}_{2}$ contents several wt\% lower than $\mathrm{SiO}_{2}$ saturation (Fig. 6). Thus, the appearance of $\mathrm{Crs}$ is not controlled by the $\mathrm{SiO}_{2}$ content of the melt, which makes $\mathrm{Crs}$ an unreliable indicator of $\mathrm{SiO}_{2}$ saturation, unlike $Q t z$ (Fig. 6). The fact that, in our database, Crs occurrences are restricted to the low $P$ region (Fig. 4C) suggests that the appearance of Crs is favoured when reaction rates become more sluggish as melt $\mathrm{H}_{2} \mathrm{O}$ content decreases and viscosity increases. $\mathrm{Crs}$ is indeed ubiquitous for $\mathrm{H}_{2} \mathrm{O}$ contents below about $1.5 \mathrm{wt} \%$ (Fig. 6), although not present in $\mathrm{H}_{2} \mathrm{O}$-undersaturated charges (e.g. absent in the 200-MPa HTN charge at $1200{ }^{\circ} \mathrm{C}$ with a melt $\mathrm{H}_{2} \mathrm{O}$ content of 1.1 wt\%; 1200_1.0, Tab. 2), suggesting that $\mathrm{H}_{2} \mathrm{O}$ saturation is a prerequisite for Crs appearance. Also, the Crs-bearing PEL charge that is at $\mathrm{H}_{2} \mathrm{O}$ saturation and contains no excess $\mathrm{H}_{2} \mathrm{O}$ vapour (VM100, Tab. 2; Fig. 3B), indicates that a vapor phase in excess is not necessary for Crs crystallization from the melt. Yet, when the amount of free vapour $\mathrm{H}_{2} \mathrm{O}$ is high enough, the primary prismatic Crs coexists with 'fish-scale' Crs mineralized from the vapour phase in gas bubbles (e.g. PEL charges D5, Tab. 2; Fig. 5C). Chemistries of experimental Crs (Tab. 2) indicate significant deviations from the pure $\mathrm{SiO}_{2}$ composition expected for a stable Crs. We conclude that (1) the $T$ range of $C r s$ occurrences, (2) the possible $\mathrm{SiO}_{2}$-undersaturated nature of the coexisting melts and (3) the Crs compositions deviating from pure $\mathrm{SiO}_{2}$, all suggest a mechanism of metastable crystallization for $\mathrm{Crs}$.

\section{Influence of reaction kinetics and melt composition on the silica phase crystallization}

In simple systems, $Q t z$ has a simple and dense structure, whereas $C r s$ and $\operatorname{Tr} d$ have more open structures. As such, the solid-state transformation from $\mathrm{Crs}$ to $\mathrm{Qtz}$ is energetically unfavourable because it involves a 'reconstructive' transformation, with the breaking up and reforming of the Si-O framework that demands high activation energy (e.g. Deer et al., 2004; 
Lakshtanov et al., 2007). Inversions (e.g. transformations from $Q t z$ to $\operatorname{Trd}$ and $\operatorname{Trd}$ to $\mathrm{Crs}$ ) are also difficult because they are kinetically inhibited (Holmquist, 1961; Roy \& Roy, 1964; Dapiaggi et al., 2015 and references therein). Crystallization of silica phases from amorphous materials (e.g. melts) can be either thermodynamically/kinetically inhibited or produce metastable assemblages. For example, neither $\operatorname{Tr} d$ nor $Q t z$ could be crystallized in and near the binary join albite-silica at 0.1 MPa, and Crs formed instead (Schairer \& Bowen, 1947a; 1956). In the same way, in and near the binary join leucite-silica at $0.1 \mathrm{MPa}, \operatorname{Tr} d$ did not appear and Crs formed (Schairer \& Bowen, 1947a; b; 1955). In the simple systems above, however, these kinetic difficulties have been overcome, leading to equilibrium data on stabilities of the different silica polymorphs (Fig. 2). However, there is no requirement that equilibrium is established in volcanic systems (e.g. Pichavant et al., 2007). Therefore, the use of equilibrium results should be questioned.

In our experiments on rhyolitic melts, the charge (925PEL25, Tab. 2) that co-crystallized Qtz and $C r s$ in the stability field of $\operatorname{Tr} d$, suggests that $\operatorname{Tr} d$ crystallization was kinetically inhibited relative to $Q t z$ and $C r s$. This situation has been encountered previously. For instance, $C r s$ persists in the $\operatorname{Trd}$ domain to at least $150{ }^{\circ} \mathrm{C}$ lower than the stable $\operatorname{Trd}$-Crs inversion (1470 ${ }^{\circ} \mathrm{C}$ ) at $0.1 \mathrm{MPa}$ and in the presence of $\mathrm{NaAlSiO}_{4}$ and $\mathrm{CaAl}_{2} \mathrm{SiO}_{4}$ melts. Conversely, in presence of $\mathrm{KAlSi}_{3} \mathrm{O}_{8}$ melt, the $\mathrm{Trd}$ stability domain extends up to $1500{ }^{\circ} \mathrm{C}$ in the $\mathrm{Crs}$ domain (Roy \& Roy, 1964). In binary alkali oxide-silica melts at $0.1 \mathrm{MPa}, Q t z$ did not form whereas Crs was stabilized in the sodic composition and both Trd and Crs coexisted in the potassic composition at $800{ }^{\circ} \mathrm{C}$ (Venezia et al., 2001). It is worth pointing out that in the volcanologically relevant albite-silica and leucite-silica systems, $\operatorname{Trd}$ appeared as soon as ternary peralkaline (molar alkali concentration, either $\mathrm{Na}_{2} \mathrm{O}$ or $\mathrm{K}_{2} \mathrm{O},>\mathrm{Al}_{2} \mathrm{O}_{3}$ concentration) compositions were crystallized instead of the binary (Schairer \& Bowen, 1947a; 1955; 1956). This demonstrates that, in addition to reaction kinetics, melt composition has an effect on the mechanism of $\operatorname{Trd}$ crystallization. In the ternary system anorthite-leucite-silica at $0.1 \mathrm{MPa}$, Crs also formed instead of $\operatorname{Tr} d$ for compositions in the $\operatorname{Tr} d$ stability field and persisted for 'more than a month' (Schairer \& Bowen, 1947b), which provides an indication of the minimum timescales needed for the transformation of a $\operatorname{Crs}$ (metastable) to a $\operatorname{Tr} d$ (stable) assemblage in this system.

In compositionally complex systems, the studies attempting to constrain the mutual relations between the different polymorphs agree that melt chemistry plays an important role in favouring one silica polymorph over the other. In general, the presence of Crs at 'low' $T$ 
outside its stability domain is attributed to the stabilizing influence of $\mathrm{Na}, \mathrm{K}$ and $\mathrm{Al}$ in its crystal structure (Roy \& Roy, 1964; Chao \& Lu, 2002; Dappiagi et al., 2015; Liang et al., 2017; Schipper et al., 2020). In-situ investigations show that $Q t z$-alkali oxide mixtures reacted in the $\operatorname{Trd}$ stability field first crystallize $\operatorname{Crs}$ in greater proportions for the sodic than the potassic system. $T r d$ then crystallizes second with an expanded cell volume and progressively replaces early Crs (Dappiagi et al., 2015). The contrasted stabilizing influences of alkali, i.e. Na stabilizing more $C r s$ and $\mathrm{K}$ more $\mathrm{Trd}$, can be understood in terms of the respective size of the stabilizing ion and of the cell in the structure of the silica polymorph (Holmquist, 1961; Venezia et al., 2001; Dappiagi et al., 2015). This chemical model, although very qualitative, is consistent with the stabilization of $\mathrm{Crs}$ in our experiments (Tab. 3), since the investigated rhyolites are sodic and contain relatively little $\mathrm{K}_{2} \mathrm{O}$ and/or normative orthoclase $\left(\mathrm{KAlSi}_{3} \mathrm{O}_{8}\right.$; Tab. 1). Therefore, the combination of low $\mathrm{H}_{2} \mathrm{O}$ contents (high viscosity) and melts with 'impurities', such as natural rhyolitic melts, likely creates favourable conditions for the crystallization of metastable Crs. However, the stabilizing mechanism is complex and catalytic processes involving elements not substituted in the structure have been identified (e.g. V; Bruhn \& Fischer, 2001).

\section{Volcanological implications}

The results from this study reveal a fundamental difference between occurrences of silica polymorphs in silicic magmas. $Q t z$ is an indicator of near-equilibrium crystallization processes at various depths in volcanic plumbing systems, whereas $\mathrm{Crs}$ and $\mathrm{Tr} d$ only record shallow crystallization processes in subsurface volcanic conduits and domes. Below, this difference is elaborated further and illustrated by natural examples.

All rhyolitic compositions investigated in this study lack a silica phase on their liquidus (Fig. 4A-B). This can be explained by the rhyolites having bulk $\mathrm{SiO}_{2}$ concentrations (70-77 wt\%; Tab. 1) lower than required for silica saturation at $\leq 100 \mathrm{MPa}$ (Fig. 6). Other $\mathrm{SiO}_{2}$-rich rhyolitic magmas, equilibrated at low $P$ (e.g. Novarupta, 77.5 wt $\% \mathrm{SiO}_{2}$ ), show similar behaviour with plagioclase and Fe-Ti oxides as liquidus phases (Coombs \& Gardner, 2001). In contrast, one of the synthetic compositions $\left(78 \mathrm{wt} \% \mathrm{SiO}_{2}\right)$ investigated by Brugger et al. (2003) has a silica phase (apparently Qtz, although not confirmed) on the liquidus at $0.1 \mathrm{MPa}$, a case which seems exceptional. Although rare on the liquidus, Qtz is a systematic subliquidus phase in the rhyolitic compositions investigated (Fig. 4B) and in examples from the 
literature (Coombs \& Gardner, 2001; Brugger et al., 2003), implying that Qtz can crystallize as a stable phenocryst in rhyolitic magmas for a wide range of $P-T$ conditions and thus be used to record the pre-eruptive conditions in silicic magma storage zones (e.g. Breiter et al., 2012). This conclusion also applies in the case of less silicic intermediate arc magmas since $Q t z$ is a late phase in experimental crystallization sequences of andesites to dacites (e.g. Barclay et al., 1998; Holtz et al., 2005; Scaillet \& Evans, 1999). However, in such intermediate magma compositions, an advanced crystallization of the magma is necessary for $Q t z$ to reach saturation in the residual melt.

In addition to constraining pre-eruptive conditions in magma storage zones, $Q t z$ occurrences are useful indicators of melt evolution and $P-T$ conditions during syn-eruptive magma ascent and degassing. Our experimental results show that $Q t z$ saturation at $P \leq 100 \mathrm{MPa}$ requires silica-rich residual melts/groundmasses $\left(\sim 80 \mathrm{wt} \% \mathrm{SiO}_{2}\right.$ recalculated on a volatile-free basis; Fig. 6). As a first illustration, the $1530 \mathrm{AD}$ sub-Plinian eruption of La Soufrière of Guadeloupe produced pumices with $Q t z$ microlites/microphenocrysts (Fig. 1A). Since $Q t z$ is absent as a phenocryst in this magma (Pichavant et al., 2018), it likely crystallized during magma ascent from a residual melt having 79.2-80.2 wt $\% \mathrm{SiO}_{2}$ and 1.8-3.2 wt $\% \mathrm{H}_{2} \mathrm{O}$ (Pichavant et al., 2018) corresponding to $P$ of $25-75 \mathrm{MPa}$ (using the $\mathrm{H}_{2} \mathrm{O}$ solubility model of Newman \& Lowenstern, 2002). At $25-75 \mathrm{MPa}$ and $\sim 825{ }^{\circ} \mathrm{C}$ (the coldest pre-eruptive $T$; Pichavant et al., 2018), and for the residual glass $\mathrm{SiO}_{2}$ and $\mathrm{H}_{2} \mathrm{O}$ contents, $Q t z$ is expected to crystallize (Figs 4B, 6), in agreement with the natural samples. A second example concerns the P1 and P2 Plinian eruptions of Montagne Pelée in La Martinique, which yielded silicaphase-free pumices hosting residual glasses with 73.4-76.7 wt $\% \mathrm{SiO}_{2}$ and 1.8-2.5 wt $\% \mathrm{H}_{2} \mathrm{O}$ (Martel \& Poussineau, 2007), which corresponds to a $P$ of 25-50 MPa (Newman \& Lowenstern, 2002). Although at 25-50 MPa and $875^{\circ} \mathrm{C}$ (pre-eruptive T, Martel et al., 1998), $Q t z$ would be expected to crystallize (i.e. below the PEL curve in Fig. 4B), plotting the $\mathrm{SiO}_{2}$ and $\mathrm{H}_{2} \mathrm{O}$ contents of the residual glasses in Fig. 6 suggests that they are far away from $Q t z$ saturation in the PEL experiments, and thus cannot crystallize $Q t z$. A third example concerns the 1902 and 1929 pyroclastic flows and surges at Montagne Pelée, which produced Crsbearing clasts, showing both primary ('prismatic') and vapour-deposited ('fish-scale') crystals (Boudon et al., 2015; Fig. 1C-D). These occurred in residual glasses having 76.9 to $80.1 \mathrm{wt} \%$ $\mathrm{SiO}_{2}$ and less than $1 \mathrm{wt} \% \mathrm{H}_{2} \mathrm{O}$ (Martel \& Poussineau, 2007) and the glass $\mathrm{H}_{2} \mathrm{O}$ contents suggest a $P$ range below $10 \mathrm{MPa}$ for a magma $T$ of $\sim 875^{\circ} \mathrm{C}$ (Martel et al., 1998). Both, the $P$ $T$ range and the glass $\mathrm{SiO}_{2}$ and $\mathrm{H}_{2} \mathrm{O}$ composition meet the conditions of $C r s$ crystallization in 
the PEL experiments (Fig. 4C, 6), which is confirmed by the natural samples. These three examples highlight that experimentally-determined constraints on silica phase saturation combined with natural sample data on $P-T$ crystallization conditions and residual glass $\mathrm{SiO}_{2}$ and $\mathrm{H}_{2} \mathrm{O}$ contents may provide a useful framework for interpreting conduit crystallization processes and predicting silica phase occurrences in natural samples.

Overall, Qtz occurs at depths of magmatic reservoirs and volcanic conduits (i.e. > 25-30 $\mathrm{MPa}$ ), whereas Crs typically crystallizes at shallower, subsurface conditions, such as in a lava dome, provided that the residence time is long enough to nucleate and grow the silica phase. For Crs, this residence time is $\geq 2$ days (Mollard et al., 2012) and is confirmed by the run durations of the charges containing $\operatorname{Crs}$ (Tab. 2). In lava domes, extensive degassing- and cooling-induced crystallization of feldspar microlites drives the matrix towards increasing melt $\mathrm{SiO}_{2}$ contents and vapour excess, which both foster conditions conducive to $\mathrm{Crs}$ formation. These conditions produce primary 'prismatic' crystals grown from the melt and 'fish-scale' crystals deposited from the vapour phase, respectively. If the magma resides long enough, 'feathery' Crs formation by glass devitrification can also occur. Concurrent microlite and Crs crystallization may generate gas overpressures capable of overcoming the strength of the magma, contributing to the mechanism proposed for the triggering of high-energy surges such as those of 1902 at Montagne Pelée (Martel, 2012).

The experiments suggest that two silica polymorphs do not coexist at equilibrium for given $P$ $T$ conditions, so that in volcanic products, the presence of more than one silica polymorph may indicate distinct conditions of crystallization. For example, the rhyolitic pumices erupted during the Plinian event of May 2008 at Chaíten contain 0.6-2.3 wt\% Qtz (and traces of Crs), whereas the domes that followed the Plinian event contain 1.5-2.0 wt\% Qtz and 14-19 wt\% Crs (Horwell et al., 2010). Such a difference between proportions of Qtz and Crs in pyroclasts is quite systematic, with $Q t z$ barely exceeding a few vol\% (e.g. Luhr \& Melson, 1996; Barclay et al., 1998; Damby et al., 2013) and Crs reaching up to 30 vol\% in some dome samples (e.g. Baxter et al., 1999; Boudon et al., 2015; Kushnir et al., 2016). Our results suggest that Qtz could have crystallized at depth in the volcanic conduit during magma ascent, thus explaining its presence in both the Plinian and the dome samples. Fragmentation of the Plinian magma likely occurred at a $P$ higher than the stability $P$ of $C r s$, whereas the magma residing in dome 
crystallized Crs in significant amounts, so that both silica polymorphs eventually coexisted in the dome samples.

From theoretical constraints (Fig. 2A), $\mathrm{Trd}$ should crystallize from $\mathrm{SiO}_{2}$-saturated melts at low $P\left(\mathrm{H}_{2} \mathrm{O}\right.$-poor $)$ and hot conditions. Using the haplogranite system as a model, $T r d$ would appear for $\sim 80 \mathrm{wt} \% \mathrm{SiO}_{2}$ melts at $<25 \mathrm{MPa}$ or $<1.5 \mathrm{wt} \% \mathrm{H}_{2} \mathrm{O}$ in the melt (Fig. 6) and above $\sim 900{ }^{\circ} \mathrm{C}$. These conditions are rarely encountered in arc volcanic systems, where an elevated $\mathrm{SiO}_{2}$ concentration of the residual melt requires extensive magma crystallization at $T<900$ ${ }^{\circ} \mathrm{C}$ for initially $\mathrm{H}_{2} \mathrm{O}$-rich magmas (Martel et al., 1999; Scaillet \& Evans, 1999; Pichavant et al., 2018). Yet, one notable example of crystallization under the above conditions is provided by the dacites of the 1980-1986 dome of Mount Saint Helens. In these rocks, Trd is interpreted to replace $Q t z$ as the silica saturating phase in the groundmass when $P$ decreased below $11 \mathrm{MPa}$ upon magma ascent, for a $T$ estimated at $\sim 900{ }^{\circ} \mathrm{C}$ (Blundy \& Cashman, 2001). Another reason for the $\operatorname{Tr} d$ rarity is that its crystallization is kinetically inhibited relative to $C r s$ and $Q t z$ (see section above). As an illustration, some andesite samples from the domerelated 2017 pyroclastic flows of Bezymianny, Kamchatka, contain Crs as the sole crystalline silica phase whereas others only contain $\operatorname{Trd}$ (Fig. 1B; Tab. 3). All samples have residual glasses with similar rhyolitic compositions (77-78 wt\% $\mathrm{SiO}_{2}$; V.O. Davydova, pers. comm.). Therefore, the growth environment was chemically the same for the two polymorphs and an influence of the type of stabilizing cations (i.e. Na versus K; see section above) is unlikely. One possible explanation is that the $C r s$-bearing and $T r d$-bearing samples resided for different durations and/or at different $T$ in the dome before being erupted. Samples with either a longer residence time or a higher $T$ could have transformed to the stable $\operatorname{Tr} d$-bearing assemblage whereas, in those with a shorter residence time or a lower $T$ in the dome, the early metastable Crs-bearing assemblage persisted. This hypothesis, which remains to be tested further, stresses the potential of using $C r s$ and $\operatorname{Trd}$ to constrain crystallization kinetics in lava domes.

\section{CONCLUSIONS}

From our compiled database that includes published and new experimental results, covering both synthetic and natural high- $\mathrm{SiO}_{2}$ melts, we conclude that: 
- Quartz (1) has near end-member composition in both experiments and nature, so that its stability limit determined in simple systems (e.g. $\mathrm{SiO}_{2}, \mathrm{SiO}_{2}-\mathrm{H}_{2} \mathrm{O}$, haplogranite) is applicable to natural silicic magmas; (2) occurs for a narrow range of melt $\mathrm{SiO}_{2}$ content and is a reliable indicator of melt $\mathrm{SiO}_{2}$ saturation; (3) is a stable phase in natural silicic magmas; and (4) is a useful indicator of relatively deep-seated crystallization processes, from magma storage zones to volcanic conduits.

- Cristobalite (1) crystallization is strongly enhanced in natural magmas compared to pure systems; (2) from experimental rhyolitic melts readily incorporates impurities ( $\mathrm{Al}$ and alkalis), in agreement with natural magmatic Crs chemistries; (3) crystallizes in melts with a large range of $\mathrm{SiO}_{2}$ content and is thus not a reliable indicator of silica saturation; (4) is a metastable phase in natural silicic magmas; and (5) preferentially forms at low- $P(<25 \mathrm{MPa})$ conditions typical of lava domes.

- Tridymite (1) was not observed in the investigated range of $P$-T-composition conditions, despite having experimental data from within its theoretical stability field; (2) has chemistries that deviate substantially from 'pure' $\mathrm{SiO}_{2}$, so that its stability limit determined in simple systems should not be applied directly to natural cases; and (3) crystallization is kinetically inhibited relative to $C r s$, but there is agreement that $\operatorname{Tr} d$ should form in $\mathrm{SiO}_{2}$-saturated melts at $>900{ }^{\circ} \mathrm{C}$ and low $P$, such as in lava domes.

\section{ACKNOWLEDGMENTS}

We would like to thank P. Robion and S. Peralta for the access to the Microscopy and Analysis platform of the i-MAT federation (CY Cergy Paris Université, Neuville/Oise, France) and C. Ferreira Cerqueira for the help with the SEM-Raman analyses. The authors thank Yves Feisel for support on the microprobe and M. Busuttil for having initiated the study during her Master 1 student course. The authors are very grateful to Roland Stalder, C. Ian Schipper, and an anonymous reviewer for their fruitful comments that certainly improved the manuscript, and to Andreas Audétat for the careful editorial handling of the manuscript.

\section{FUNDING}


The French CNRS-INSU_TelluS program, the PLANEX project (ANR-11-EQPX-0036), and the VOLTAIRE project (ANR-10-LABX-100-01) funded by ANR through the PIA (Programme Investissement d'Avenir) are gratefully acknowledged.

\section{REFERENCES}

Barclay, J., Rutherford, M.J., Carroll, M.R., Murphy, M.D. \& Devine, D. (1998). Experimental phase equilibria constraints on preeruptive storage conditions of the Soufriere Hills magma. Geophysical Research Letters 25, 3437-3440.

Baxter, P.J., Bonadonna, C., Dupree, R., Hards, V.L., Kohn, S.C., Murphy, M.D., Nichols, A., Nicholson, R.A., Norton, G., Searl, A., Sparks, R.S.J. \& Vickers, B.P. (1999). Cristobalite in volcanic ash of the Soufriere Hills Volcano, Montserrat, British West Indies. Science 283, 1142-1145.

Blundy, J. \& Cashman, K. (2001). Ascent-driven crystallization of dacite magma at Mount St Helens, 1980-1986. Contributions to Mineralogy and Petrology 140, 631-650.

Boettcher, A.L. (1984). The system $\mathrm{SiO}_{2}-\mathrm{H}_{2} \mathrm{O}-\mathrm{CO}_{2}$ : melting, solubility mechanisms of carbon, and liquid structure to high pressures. American Mineralogist 69, 823-833.

Boettcher, A., Guo, Q., Bohlen, S. \& Hanson, B. (1984). Melting in feldspar-bearing systems to high pressures and the structures of aluminosilicate liquids. Geology 12, 202-204.

Boudon, G., Balcone-Boissard, H., Villemant, B. \& Morgan D.J. (2015). What factors control superficial lava dome explosivity? Scientific Reports 5, 14551.

Breiter, K., Svojtka, M., Ackerman, L. \& Švecová, K. (2012) Trace element composition of quartz from the Variscan Altenberg-Teplice caldera (Krušné hory/Erzgebirge Mts, Czech Republic/Germany): Insights into the volcano-plutonic complex evolution. Chemical Geology 326-327, 36-50.

Brugger C.R., Johnston A.D. \& Cashman K.V. (2003). Phase relations in silicic systems at one-atmosphere pressure. Contributions to Mineralogy and Petrology 146, 356-369.

Bruhns, P. \& Fischer R.X. (2000). Crystallization of cristobalite and tridymite in the presence of vanadium. European Journal of Mineralogy 12, 615-624. 
Castro, J.M. \& Dingwell, D.B. (2009). Rapid ascent of rhyolitic magma at Chaíten volcano, Chile. Nature 461, 780-784.

Castro, J.M., Schipper, C.I., Mueller, S.P., Militzer, A.S., Amigo, A., Silva Parejas, C. \& Jacob, D. (2013). Storage and eruption of near-liquidus rhyolite magma at Cordón Caulle, Chile. Bulletin of Volcanology 75, 702.

Chao, C.H. \& Lu, H.Y. (2002). beta-cristobalite stabilization in $\left(\mathrm{Na}_{2} \mathrm{O}+\mathrm{Al}_{2} \mathrm{O}_{3}\right)$-added silica. Metallurgical and Materials Transactions a-Physical Metallurgy and Materials Science 33(8), 2703-2711.

Chesner, C.A. (1998). Petrogenesis of the Toba Tuffs, Sumatra, Indonesia. Journal of Petrology 39, 397-438.

Coombs, M.L. \& Gardner, J.E. (2001). Shallow-storage conditions for the rhyolite of the 1912 eruption at Novarupta, Alaska. Geology 29, 775-778.

Conrad, W.K., Nicholls, I.A. \& Wall, V.J. (1988). Water-Saturated and -undersaturated melting of metaluminous and peraluminous crustal compositions at $10 \mathrm{~kb}$ : evidence for the origin of silicic magmas in the Taupo volcanic zone, New Zealand, and other occurrences. Journal of Petrology 29, 765-803.

Damby, D.E., Horwell, C.J., Baxter, P.J., Delmelle, P., Donaldson, K., Dunster, C., Fubini, B., Murphy, F.A., Nattrass, C., Sweeney, S., Tetley, T.D. \& Tomatis, M. (2013). The respiratory health hazard of tephra from the 2010 Centennial eruption of Merapi with implications for occupational mining of deposits. Journal of Volcanology and Geothermal Research 261, 376-387.

Damby, D.E, Murphy, F.A., Horwell, C.J., Raftis, J. \& Donaldson, K. (2016). The in vitro respiratory toxicity of cristobalite-bearing volcanic ash. Environmental Research 145, 7484.

Dapiaggi, M., Pagliaria, L. Pavese, A., Sciascia, L., Merli, M. \& Francescond, F. (2015). The formation of silica high temperature polymorphs from quartz: influence of grain size and mineralising agents. Journal of European Ceramic Society 35, 4547-4555.

Deer, W.A., Howie, R.A., Wise, W.S. \& Zussman, J. (2004). Framework silicates: silica minerals, felspathoids and zeolites. Rock-forming minerals, vol. 4B, Geol. Soc., 963 pp. 
de Hoog, J.C.M., van Bergen, M.J. \& Jacobs, M.H.G. (2005). Vapour-phase crystallisation of silica from $\mathrm{SiF}_{4}$-bearing volcanic gases. Annals of Geophysics 48(4-5), 775-785.

Devine, J.D., Barclay, J. Carroll, M.R., Murphy, M.D., Rutherford, M., Sparks, R.S.J. \& Young, S.R. (1998). Petrologic evidence for pre-eruptive pressure-temperature conditions, and recent reheating, of andesitic magma erupting at the Soufriere Hills Volcano, Montserrat, W.I. Geophysical and Research Letters 25, 3669-3672.

Devineau, K., Champallier, R. \& Pichavant, M. (2020). Dynamic crystallization of a haplogranitic melt - application to pegmatites. Journal of Petrology 61(5), doi: 10.1093/petrology/egaa054.

Hammer, J.E. \& Rutherford, M.J. (2002). An experimental study of the kinetics of decompression-induced crystallization in silicic melts. Journal of Geophysical Research 107, ECV8, 1-23.

Heaney, P.J. (1994). Structure and chemistry of the low-pressure silica polymorphs. In: Heaney, P.J, Prewitt, C.T. \& Gibbs G.V. (ed.) Reviews in Mineralogy and Geochemistry 29, $1-40$.

Hirschmann, M.M., Ghiorso, M.S., Davis, F.A., Gordon, S.M., Mukherjee, S., Grove, T.L., Krawcczynski, M., Médard, E. \& Till, C.E. (2008). Library of experimental phase relations (LEPR): a database and web portal for experimental magmatic phase equilibria data. Geochemistry Geophysics Geosystems 9, Q03011, doi:10.1029/2007GC001894.

Holmquist, S.B. (1961). Conversion of quartz to tridymite. Journal of American Ceramic Society 44, 82-86.

Holtz, F., Sato, H., Lewis, J., Behrens, H. \& Nakada, S. (2005). Experimental petrology of the 1991-1995 Unzen dacite, Japan. Part I: phase relations, phase composition and preeruptive conditions. Journal of Petrology 46, 319-337.

Holtz, F., Becker, A., Freise, M. \& Johannes W. (2001). The water-undersaturated and dry Qz-Ab-Or system revisited. Experimental results at very low water activities and geological implications. Contributions to Mineralogy and Petrology 141, 347-357.

Horwell, C.J., Le Blond, J.S., Michnowicz, S.A.K. \& Cressey, G. (2010). Cristobalite in a rhyolitic lava dome: evolution of ash hazard. Bulletin of Volcanology 72, 249-253. 
Horwell, C., Williamson, B., Donaldson, K., Le Blond, J., Damby, D. \& Bowen, L. (2012). The structure of volcanic cristobalite in relation to its toxicity; relevance for the variable crystalline silica hazard. Particle and Fibre Toxicology 9, 44.

Horwell, C.J., Williamson, B.J., Llewellin, E.W., Damby, D.E. \& Le Blond, J.S. (2013). The nature and formation of cristobalite at the Soufrière Hills volcano, Montserrat: implications for the petrology and stability of silicic lava domes. Bulletin of Volcanology 75, 696-713.

Ivanova, D.A., Shcherbakov, V.D., Plechov, P.Y, Nekrylov, N.A., Davydova, V.O., Turova, M.A. \& Stepanov, O.V. (2018). Cristobalite in extrusive rocks of Bezymianny volcano. New data on minerals 52, 51-58.

Kracek, F.C., Bowen, N.L. \& Morey, G.W. (1937). Equilibrium relations and factors influencing their determination in the system $\mathrm{K}_{2} \mathrm{SiO}_{3}-\mathrm{SiO}_{2}$. Journal of Physical Chemistry 41, 1183-1193.

Kushnir, A.R.L., Martel, C., Bourdier, J.-L., Heap, M.J., Reuschle, T., Erdmann, S., Komorowski, J.-C. \& Cholik, N. (2016). Probing permeability and microtexture: unravelling the role of a low-permeability dome on the explosivity of Merapi (Indonesia). Journal of Volcanology and Geothermal Research 316, 56-71.

Lakshtanov, D.L., Sinogeikin, S.V. \& Bass, J.D. (2007). High-temperature phase transitions and elasticity of silica polymorphs. Physics and Chemistry of Minerals 34, 11-22.

Liang, J.J., Lin, Q.H., Zhang, X., Jin, T., Zhou, Y.Z., Sun, X.F., Choi, B.G., Kim, I.S., Do, J.H. \& Jo, C.Y. (2017). Effects of Alumina on Cristobalite Crystallization and Properties of Silica-Based Ceramic Cores. Journal of Materials Science \& Technology 33, 204-209.

Luhr, J.F. \& Melson, W.G. (1996). Mineral and glass compositions in June 15, 1991, pumices: evidence for dynamic disequilibrium in the Pinatubo dacite. In: Newhall, C.G. \& Punongbayan, R.S. (ed.) Fire and Mud. Eruptions and Lahars of Mount Pinatubo, Philippines. Seattle: University of Washington Press, 733-750.

Luth, W.C. (1976). Granitic rocks. In: Bailey, D.K. \& MacDonald, R. (ed.) The evolution of crystalline rocks. Academic Press, London, 335-417.

Luth, W.C., Jahns, R.H. \& Tuttle, O.F. (1964). The granitic system at pressure of 4 to 10 kilobars. Journal of Geophysical Research 69, 759-773. 
Martel, C. (2012). Eruption dynamics inferred from microlite crystallization experiments: Application to Plinian and dome-forming eruptions of Mt. Pelée (Martinique, Lesser Antilles). Journal of Petrology 53(4), 699-725.

Martel, C, Bourdier, J.-L., Pichavant, M. \& Traineau, H. (2000). Textures, water content and degassing of silicic andesites from recent plinian and dome-forming eruptions at Mount Pelée volcano (Martinique, Lesser Antilles arc). Journal of Volcanology and Geothermal Research 96, 191-206.

Martel, C., Pichavant, M., Bourdier, J.-L., Traineau, H., Holtz, F. \& Scaillet, B. (1998). Magma storage conditions and control of eruption regime in silicic volcanoes: experimental evidence from Mt. Pelée. Earth and Planetary Science Letters 156, 89-99.

Martel, C., Pichavant, M., Holtz, F., Scaillet, B., Bourdier, J.-L. \& Traineau, H. (1999). Effect of $\mathrm{fO}_{2}$ and $\mathrm{H}_{2} \mathrm{O}$ on andesite phase relations between 2 and 4 kbar. Journal of Geophysical Research 104(B12), 29453-29470.

Martel, C. \& Poussineau, S. (2007). Diversity of eruptive style inferred from the microlites of Mt. Pelée andesite (Martinique, Lesser Antilles). Journal of Volcanology and Geothermal Research 166, 233-254.

Martel, C. \& Schmidt B.C. (2003). Decompression experiments as an insight into magma ascent rates. Contributions to Mineralogy and Petrology 144, 397-415.

Mollard, E., Martel, C. \& Bourdier, J.-L. (2012). Decompression-induced experimental crystallization in hydrated silica-rich melts: empirical models of plagioclase nucleation and growth kinetics. Journal of Petrology 53, 1743-1766.

Nakada, S. \& Motomura, Y. (1999). Petrology of the 1991-95 eruption at Unzen: effusion pulsation and groundmass crystallization. Journal of Volcanology and Geothermal Research 89, 173-196.

Nattrass, C, Horwell, C.J., Damby, D.E., Brown, D. \& Stone, V. (2017) The effect of aluminium and sodium impurities on the in vitro toxicity and pro-inflammatory potential of cristobalite. Environnemental Research 159, 164-175.

Newman, S. \& Lowenstern, J.B. (2002). VOLATILECALC: a silicate melt- $\mathrm{H}_{2} \mathrm{O}-\mathrm{CO}_{2}$ solution model written in Visual Basic for excel. Computers \& Geosciences 28(5), 597-604. 
Papike, J.J. \& Cameron, M. (1976). Crystal chemistry of silicate minerals of geophysical interest. Reviews of Geophysics and Space Physics 14, 37-80.

Pallister, J.S., Thornber, C.R., Cashman, K.V., Clynne, M.A., Lowers, H.A., Mandeville, C.K., Brownfield, I.K. \& Meeker, G.P. (2008). Chapter 30. Petrology of the 2004-2006 Mount St. Helens lava dome-implications for magmatic plumbing and eruption triggering. In: Sherrod, D.R., Scott, W.E. \& Stauffer, P.H. (ed.) A volcano rekindled: the renewed eruption of Mount St. Helens, 2004-2006. U.S. Geological Survey Professional Paper 1750, 647-702.

Pevear, D.R., Dethier, D.P. \& Frank, D. (1982). Clay minerals in the 1980 deposits from Mount St. Helens. Clays and Clay Minerals 30, 241-252.

Pichavant, M., Costa, F., Burgisser, A., Scaillet, B., Martel, C. \& Poussineau, S. (2007). Equilibration scales in silicic to intermediate magmas - implications for experimental studies. Journal of Petrology 48, 1955-1972.

Pichavant, M., Poussineau, S., Lesne, P., Solaro, C. \& Bourdier, J.-L. (2018). Experimental parametrization of magma mixing: application to the AD 1530 eruption of La Soufrière, Guadeloupe (Lesser Antilles). Journal of Petrology 59, 257-282.

Prouteau, G. \& Scaillet, B. (2003). Experimental Constraints on the Origin of the 1991 Pinatubo Dacite. Journal of Petrology 44, 2203-2241.

Reich, M., Zúñiga, A., Amigo, A., Vargas, G., Morata, D., Palacios, C., Parada, M.A. \& Garreaud, R.D. (2009). Formation of cristobalite nanofibers during explosive volcanic eruptions. Geology 37, 435-438.

Roy, D.M. \& Roy, R. (1964). Tridymite-cristobalite relations and stable solid solutions. American Mineralogist 49, 952-962.

Rutherford, M.J. \& Devine, J.D. (1996). Pre-eruption pressure-temperature conditions and volatiles in the 1991 Mount Pinatubo magma. In: Newhall, C.G. \& Punongbayan, R.S. (ed.) Fire and Mud. Eruptions and Lahars of Mount Pinatubo, Philippines. Seattle: University of Washington Press, 751-766. 
Scaillet, B. \& Evans, B.W. (1999). The 15 June 1991 Eruption of Mount Pinatubo. I. Phase Equilibria and Pre-eruption $\mathrm{P}-\mathrm{T}-\mathrm{fO}_{2}-\mathrm{fH}_{2} \mathrm{O}$ Conditions of the Dacite Magma. Journal of Petrology 40, 381-411.

Schairer, J.F. (1950). The alkali-feldspar join in the system $\mathrm{NaAlSiO}_{4}-\mathrm{KAlSiO}_{4}-\mathrm{H}_{2} \mathrm{O}$. Journal of Geology 58(5), 512-517.

Schairer, J.F. \& Bowen N.M. (1935). Preliminary report on equilibrium relations between feldspathoids, alkali feldspars and silica. American Geophysical Union Trans, 16th Annual Meeting, 325-328.

Schairer, J.F. \& Bowen, N.L. (1947a). Melting relations in the systems $\mathrm{Na}_{2} \mathrm{O}-\mathrm{Al}_{2} \mathrm{O}_{3}-\mathrm{SiO}_{2}$ and $\mathrm{K}_{2} \mathrm{O}-\mathrm{Al}_{2} \mathrm{O}_{3}-\mathrm{SiO}_{2}$. American Journal of Science 245, 193-204.

Schairer, J.F. \& Bowen, N.L. (1947b). The system anorthite-leucite-silica. Bulletin of the Geological Society of Finland 20, 67-87.

Schairer, J.F. \& Bowen, N.L. (1955). The system $\mathrm{K}_{2} \mathrm{O}-\mathrm{Al}_{2} \mathrm{O}_{3}-\mathrm{SiO}_{2}$. American Journal of Science 253, 681-746.

Schairer, J.F. \& Bowen, N.L. (1956). The system $\mathrm{Na}_{2} \mathrm{O}-\mathrm{Al}_{2} \mathrm{O}_{3}-\mathrm{SiO}_{2}$. American Journal of Science 254, 129-195.

Schipper, C.I., Castro, J.M., Tuffen, H., Wadsworth, F.B., Chappell, D., Pantoja, A.E., Simpson, M.P. \& Le Ru, E.C. (2015). Cristobalite in the 2011-2012 Cordón Caulle eruption (Chile). Bulletin of Volcanology 77, 34-53.

Schipper, C.I., Mandon, C., Maksimenko, A., Castro, J.M., Conway, C.E., Hauer, P. Kirilova, M. \& Kilgour, G. (2017). Vapor-phase cristobalite as a durable indicator of magmatic pore structure and halogen degassing: an example from White Island volcano (New Zealand). Bulletin of Volcanology 79, 74-88.

Schipper, C.I., Rickard, W.D.A., Reddy, S.M., Saxey, D.W., Castro, J.M., Fougerouse, D., Quadir, Z., Conway, C., Prior, D.J. \& Lilly, K. (2020). Volcanic $\mathrm{SiO}_{2}$-cristobalite: A natural product of chemical vapor deposition. American Mineralogist 105, 510-524.

Smith, J.V. \& Steele, I.M. (1984). Chemical substitution in silica polymorphs. Neues Jahrbuch für Mineralogie Monatshefte 3, 137-144. 
Stern, C.R. \& Wyllie, P.J. (1981). Phase relationships of I-type granite with $\mathrm{H}_{2} \mathrm{O}$ to 35 kilobars: the Dinkey Lakes biotite-granite From the Sierra Nevada batholith. Journal of Geophysical Research 86, 10412-10422.

Stevens, S.J., Hand, R.J. \& Sharp, J.H. (1997). Polymorphism of silica. Journal of Materials Science 32(11), 2929-2935.

Stewart, D.B. (1967). Four-phase curve in the system $\mathrm{CaAl}_{2} \mathrm{Si}_{2} \mathrm{O}_{8}-\mathrm{SiO}_{2}-\mathrm{H}_{2} \mathrm{O}$ between 1 and 10 kilobars. Schweizerische Mineralogische und Petrographische Mitteilungen 47, 35-59.

Swamy, V., Saxena, S.K., Sundman, B. \& Zhang, J. (1994). A thermodynamic assessment of silica phase diagram. Journal of Geophysical Research 99, 11787-11794.

Swanson, S.E., Naney, M.T., Westrich, H.R. \& Eichelberger, J.C. (1989). Crystallization history of Obsidian Dome, Inyo Domes, California. Bulletin of Volcanology 51, 161-176.

Tuttle, O.F. \& England, J.L. (1955). A preliminary report on the system $\mathrm{SiO}_{2}-\mathrm{H}_{2} \mathrm{O}$. Geological Society of America Bulletin 66, 149-152.

Tuttle, O.F. \& Bowen, N.L. (1958). Origin of Granite in the Light of Experimental Studies in the System $\mathrm{NaAlSi}_{3} \mathrm{O}_{8}-\mathrm{KAlSi}_{3} \mathrm{O}_{8}-\mathrm{SiO}_{2}-\mathrm{H}_{2} \mathrm{O}$. Geological Society of America Memoirs 74.

Venezia, A.M., La Parola, V., Longo, A. \& Martorana, A. (2001). Effect of alkali ions on the amorphous to crystalline phase transition of silica. Journal of Solid State Chemistry 161, 373-378.

Westercamp, D. (1975). Petrology of the volcanic rocks of Martinique, West Indies. Bulletin Volcanologique 39, 175-200.

Wille, G., Schmidt, U. \& Hollricher, O. (2018). RISE: Correlative Confocal Raman and Scanning Electron Microscopy. In: Toporski, J., Dieing, T. \& Hollricher, O. (ed.) Confocal Raman Microscopy. Springer Series in Surface Sciences 66. Springer, Cham.

\section{Figure Caption}


Figure 1. SEM pictures of silica phases in natural volcanic products. (A) 'Prismatic' $Q t z$ in a pumice clast from the 1530 eruption of La Soufrière, Guadeloupe, F.W.I. (SG7B-1 sample in Pichavant et al., 2018); (B) 'Prismatic' Trd in a vesicular clast from the 2017 pyroclastic flows of Bezymianny, Kamchatka, Russia (VK18-5h-6 sample; V.O. Davydova, pers. comm.); (C) 'Fish-scale' and 'feathery' Crs in a dense clast from the 1902 August 30th surge of Montagne Pelée, Martinique, F.W.I. (MT36V15 sample in Martel \& Poussineau, 2007), and (D) 'Prismatic' Crs in the 1902 dome of Montagne Pelée (MT34M sample in Martel \& Poussineau, 2007). The black areas are pores and the white crystals are either orthopyroxenes or Fe-Ti oxides.

Figure 2. Stability of silica polymorphs in simple systems. (A) Pressure-temperature liquidus phase relations for three systems: pure $\mathrm{SiO}_{2}$ (black solid and dashed lines; modified from Heaney, 1994), $\mathrm{SiO}_{2}-\mathrm{H}_{2} \mathrm{O}$ (green solid and dashed lines; modified from Tuttle \& Bowen, 1958), and haplogranite- $\mathrm{H}_{2} \mathrm{O}$ (minimum compositions; red solid and dashed lines from Tuttle \& Bowen, 1958, and Luth, 1976). For the $\mathrm{SiO}_{2}-\mathrm{H}_{2} \mathrm{O}$ and haplogranite- $\mathrm{H}_{2} \mathrm{O}$ systems, only $\mathrm{H}_{2} \mathrm{O}$-saturated relationships are considered. Stability domains for the different silica polymorphs in the three systems are labelled using the same color coding. (B) $\mathrm{SiO}_{2}$-albite (Ab)-orthoclase (Or) ternary diagram illustrating the change from $\mathrm{Trd}$ to $Q t z$ as the stable silica polymorph on the liquidus in the haplogranite system at 0.1 and $100 \mathrm{MPa}$ (Tuttle \& Bowen, 1958); m represents minimum compositions; Qtz: quartz, Crs: cristobalite, Trd: tridymite.

Figure 3. Raman spectra characterizing crystalline silica using SEM-coupled Raman spectroscopy ('RISE' technique) in (A) HTN_950HTN1 and (B) PEL_VM100 (sample numbers as referred in Tab. 2). Qtz: quartz, Crs, cristobalite, Fsp: feldspath.

Figure 4. Silica polymorphs in natural rhyolitic melts and analogues (Tab. 1 for compositional details). (A) liquidus phase relations, (B) quartz saturation, and (C) quartzcristobalite boundary. PEL (Montagne Pelée) in dark blue; SH2 (Soufriere Hills) in pink; CHAI (Chaíten) in brown; CC (Cordón Caulle) in light blue; HPG (haplogranite) in orange; HTN (haplotonalite) in green. The subscript numbers attached to the labels in (A) give the $\mathrm{SiO}_{2}$ wt $\%$ content of the melts, as reported in Tab. 1.

Figure 5. SEM pictures of silica phases in the rhyolitic PEL series. (A) 'Prismatic' $Q t z$ in charge LPE750, (B) 'Prismatic' Crs in charge 925PEL25, and (C) 'Prismatic' and 'fish-scale' Crs coexisting in charge D5. Details on the run conditions are given in Tab. 2. The black areas 
are pores and the white crystals are either orthopyroxenes or Fe-Ti oxides. All images are at x1000 magnification.

Figure 6. Melt $\mathrm{SiO}_{2}$ contents (wt\%, recalculated anhydrous) as a function of $\mathrm{H}_{2} \mathrm{O}$ content (wt\%). For the PEL (dark blue), SH2 (pink), and CC (light blue) compositions, the data are from low pressure ( $P \leq 100 \mathrm{MPa}) \mathrm{H}_{2} \mathrm{O}$-saturated experiments (Tab. 2). For the HTN (green) composition, the data are from the $200 \mathrm{MPa} \mathrm{H}_{2} \mathrm{O}$-undersaturated experiments (Tab. 2). The haplogranite $\left(\mathrm{HPG}_{\mathrm{m}}\right)$ data (red) are from Tuttle \& Bowen (1958) and Luth (1976). Point labels are experimental temperatures. Qtz: quartz, Crs: cristobalite, $\operatorname{Trd}$ : tridymite. The lines represent the silica phase saturation or boundary from a silica phase to another (dashed line where not precisely constrained) for the different compositions. Note that for $\mathrm{HPG}_{\mathrm{m}}$ (red), the silica polymorph is $Q t z$ above and Trd below 20-30 MPa (Schairer, 1950; Tuttle \& Bowen, 1958; Fig. 2A), with an uncertain melt $\mathrm{SiO}_{2}$ content at $\mathrm{Trd}$ saturation at $0.1 \mathrm{MPa}$ (Schairer \& Bowen, 1935; Schairer, 1950; Luth, 1976). The colored areas refer to glass compositions in natural samples, such as the Qtz-bearing pumice of the $1530 \mathrm{AD}$ eruption of Soufrière of Guadeloupe (Pichavant et al., 2018), the silica-phase-free pumice of P1 and P2 Plinian fallout of Montagne Pelée, and the Crs-bearing dome products from the 1902 and 1929 domes and associated pyroclastic flows of Montagne Pelée (Martel \& Poussineau, 2007).

Table 1. Origin and composition of the studied samples.

Table 2. Experimental conditions and characterization of the silica polymorphs.

Table 3. Selected analyses of natural and experimental silica polymorphs.

SM1. Experimental and analytical methods for the new experiments.

SM2. HTN series : phase relations.

SM3. HTN series: glass and plagioclase compositions.

SM4. New glass analyses. 